\title{
Efektivitas Bimbingan dan Konseling Islam untuk Meningkatkan Penerimaan Diri pada Penyandang Tunanetra
}

\author{
Komariah $^{1}$ \\ ${ }^{1}$ IAIN Syaikh Abdurrahman Siddik Bangka Belitung
}

\begin{tabular}{ll}
\hline \hline Info Artikel : & \\
\hline & \\
Diterima & $: 24$ Februari 2019 \\
Direvisi & $: 14$ April 2019 \\
Dipublish & $: 28$ Juni 2019
\end{tabular}

Kata Kunci:

Penerimaan Diri

Bimbingan dan Konseling Islam

Penyandang Tunanetra

Keywords:

Self-Acceptance

Guidance and Islamic counseling

Visually Impaired Students

\begin{abstract}
ABSTRAK
Penelitian ini bertujuan untuk mengetahui Efektivitas Bimbingan dan Konseling Islam dalam meningkatkan Penerimaan Diri pada penyandang tunanetra pada mahasiswa difabel Pusat Layanan Difabel UIN Sunan Kalijaga Yogyakarta. Hipotesis dalam penelitian ini adalah Bimbingan Konseling Islami efektif dalam meningkatkan Penerimaan Diri pada penyandang tunanetra. Subjek yang digunakan dalam penelitian ini berjumlah lima orang mahasiswa-mahasiswi penyandang tunanetra yang dinaungi oleh Pusat Layanan Difabel Universitas Islam Negeri Sunan Kalijaga Yogyakarta. Desain eksperimen yang digunakan dalam penelitian ini yaitu QuasiExperimental design. Alat pengumpulan data menggunakan skala Penerimaan Diri yang mengacu pada aspek penerimaan diri yang dikemukakan oleh Sheerer. Analisis data menggunakan wilcoxon signed rank test dengan program SPSS 16.00 for windows. Hasil penelitian menunjukkan bahwa ada perbedaan yang signifikan antara pretest dan posttest Penerimaan Diri penyandang tunanetra. Berdasarkan hasil perhitungan statistik ini berarti Bimbingan dan Konseling Islam efektif untuk meningkatkan Penerimaan Diri pada penyandang tunanetra. Dengan demikian hipotesis yang diajukan peneliti dalam penelitian ini diterima atau terbukti. Hal ini mengindikasikan bahwa semakin efektif proses Bimbingan dan Konseling Islam, maka akan semakin meningkatkan Penerimaan Diri pada penyandang tunanetra. Begitu juga sebaliknya, semakin tidak efektif proses Bimbingan dan Konseling Islam yang diberikan, maka tidak akan efektif untuk meningkatkan Penerimaan Diri pada penyandang tunanetra.
\end{abstract}

\section{ABSTRACT}

This study aims to determine the effectiveness of Islamic Guidance and Counseling in increasing Self-Acceptance of visually impaired students with disabilities at UIN Sunan Kalijaga Yogyakarta Disability Service Center. The hypothesis in this study is that Islamic Counseling Guidance is effective in increasing Self-Acceptance of visually impaired students. The subjects in this study were five students with visual impairment who were shaded by the Disability Service Center of UIN Sunan Kalijaga Yogyakarta. The experimental design used in this study was Quasi-Experimental design. Data collection tool used was a scale of Self-Acceptance that refers to aspects of self-acceptance proposed by Sheerer. The data was analysed by using Wilcoxon signed rank test with SPSS 16.00 for Windows. The results showed that there was a significant difference between the pretest and posttest of Self-Acceptance of the visually impaired students. The results of this statistical calculation suggested that Islamic Guidance and Counseling was effective in increasing Self-Acceptance of the visually impaired students. Thus the hypothesis proposed by researchers in this study was accepted. This indicates that the more effective the Islamic Guidance and Counseling process is, the more self-acceptance will be for the visually impaired students. And vice versa, the more ineffective the process of Islamic Guidance and Counseling is given, the less effective it will be to increase selfacceptance of the visually impaired students.

\section{Koresponden:}

Komariah

Email: mariababel71@gmail.com

\section{Pendahuluan}

Jumlah penyandang Tunanetra berdasarkan Data Susenas menginformasikan bahwa dari 2,13 juta penyandang disabilitas, 339.309 orang adalah penyandang tunanetra dengan komposisi 180.009 
penyandang tunanetra laki-laki dan 159.300 penyandang tunanetra perempuan. Bila dianalisa lebih mendalam, Data Susesnas Tahun 2009 menunjukan bahwa persentase penyandang disabilitas usia 10 tahun ke atas, termasuk tunanetra laki-laki dan perempuan yang belum kawin cukup besar masing-masing 49,12 dan 45,04 persen. Di bidang pendidikan angka partisipasi sekolah penyandang disabilitas, termasuk penyandang tuna netra perempuan yang bersekolah cukup tinggi dibandingkan penyandang tunanetra laki-laki yaitu 42,70 dan 36,88 persen (Ceyhan \& Ceyhan, 2011).

Individu yang memperoleh ketunanetraan sejak lahir disebabkan oleh faktor gen, kondisi psikis ibu saat hamil, keracunan obat yang diminum oleh ibu saat hamil, ibu hamil kekurangan gizi, serta maltunasi (kekurangan gizi pada tahap embrional antara 3-8 minggu usia kehamilan), individu yang mendapat ketunanetraan setelah lahir atau bukan sejak lahir disebabkan kurang vitamin A, terkena penyakit mata, pengaruh alat medis saat dilahirkan, kecelakaan, serta terkena virus maupun racun, (Somantri, 2006).

Adapun dengan memiliki kekurangan secara fisik, para penyandang tunanetra terkadang mengalami berbagai permasalahan. Kondisi psikologis yang sering mereka rasakan seperti rasa tidak bisa menerima kondisi mereka, dan merasa berbeda dari orang lain, dan permasalahan ini tidak hanya menghambat perkembangan mereka dibidang akademik, akan tetapi secara psikologis juga mereka merasa adanya ketidakalilan dalam hidup ini, (Azmil, 2013).

Sebuah penelitian menjelaskan bahwa ada beberapa hambatan yang dirasakan oleh para penyandang tunanetra yang diklasifikasikan secara internal dan eksternal. Adapun secara internal yaitu keterbatasan fisik yang dimiliki oleh penyandang tunanetra berakibat pada diri sendiri diantaranya yaitu memiliki rasa kurang percaya diri, rendah diri berlebihan, kesulitan untuk hidup mandiri, konsep diri rendah, tidak berdaya, dan putus asa. Hal ini akan lebih dirasakan oleh tunannetra yang mengalami gangguan penglihatan bukan sejak lahir tetapi sejak usia remaja atau dewasa. Sedangkan secara eksternal penyandang tunanetra berbeda dengan orang awas. Sehingga hal ini mengakibatkan para penyandang tunannetra tidak optimal dalam mengembangkan potensi yang dimilikinya baik secara harkat, martabat, maupun kesejahteraan hidup bersama di masyarakat, (Harimukthi \& Dewi, 2017; Perianto, 2016; Yulianti, 2017)

Salah satu penyandang Tunanetra yang merasakan ini sebut saja W, salah seorang penyandang Tunanetra yang sekarang duduk dibangku kuliah, W menyandang tunanetra sejak umur 7 tahun disebabkan oleh Virus Toksoplasma. W merupakan salah satu penyandang tunanetra yang dinaungi oleh Pusat Layanan Difabel (PLD) Universitas Islam Negeri Sunan Kalijaga Yogyakarta. Pusat Layanan Difabel (PLD) UIN Sunan Kalijaga dipilih sebagai lokasi penelitian dalam tesis ini dikarenakan PLD merupakan salah satu lembaga yang menaungi para penyandang disabilitas yang dimiliki oleh UIN Sunan Kalijaga Yogyakarta.

Seorang remaja yang dilahirkan dalam kondisi normal kemudian mengalami kecelakaan dan dinyatakan menjadi penyandang tunanetra di usia remaja akan mengalami banyak perubahan dalam dirinya, baik secara fisik maupun psikologis. Perubahan yang terjadi secara tiba-tiba ini akan menimbulkan emosi negatif pada diri remaja, karena ia harus menjalani serangkaian proses penerimaan diri yang membutuhkan kurun waktu tertentu sehingga ia bisa menerima kondisi dirinya yang baru, (Gultom \& Budisetyani, 2018; Harimukthi \& Dewi, 2017; Zulfa, 2009).

Schultz mengatakan bahwa penerimaan diri adalah orang yang selalu terbuka terhadap setiap pengalaman serta mampu menerima setiap kritikan dan masukan dari orang lain. Ketidakmampuan menerima diri sebagaimana adanya dengan segala keunikannya adalah karena adanya perasaan suasana hati yang tertekan. Keadaan tertekan ini akan membuat individu membuat gambaran diri sebagai pribadi yang menderita dan pesimis (Schultz, 1991). Penerimaan Diri adalah sebagai keadaan kepribadian yang stabil, yang dihasilkan dari individu dengan estimasi diri yang relatif stabil, terutama ketika membandingkan diri dengan orang lain (Walęcka-Matyja, 2014).

Adapun aspek-aspek penerimaan diri yaitu (Sari \& Nuryoto, 2002):

1. Keyakinan akan kemampuan dalam menghadapi problem kehidupan.

2. Harga diri sebagai manusia yang sederajat dengan orang lain.

3. Perasaan tidak menyimpang dan berbeda dengan orang lain (tidak minder)

4. Sadar dan merasa tidak malu akan dirinya.

5. Tanggung jawab terhadap perilakunya

6. Objektif dalam menerima pujian atau celaan atas dirinya.

7. Tidak adanya penyalahan diri atas keterbatasan yang dimiliki ataupun pengingkaran kelebihan.

Adapun faktor-faktor yang mempengaruhi penerimaan diri pada seseorang dikemukakan oleh Hurlock adalah sebagai berikut (Hurlock, n.d.):

1. Faktor internal; Pemahaman tentang diri sendiri, harapan yang realistis, konsep diri yang stabil, penyesuaian diri, penyesuaian sosial, pendidikan dan kesuksesan atau pengetahuan diri 
2. Faktor eksternal; Pola asuh yang baik di masa kecil, dukungan sosial dan tempat tinggal.

Bimbingan dan Konseling Islam dijadikan sebagai treatment dalam penelitian ini untuk melihat seberapa efektif Bimbingan dan Konseling Islam dalam meningkatkan penerimaan diri pada penyandang tunanetra dan membantu para penyandang tunanetra agar dapat menerima dirinya seutuhnya. Sedangkan untuk materi didalam konseling ini yaitu penjelasan tentang makna Qodlo' dan Qodar, potensi atau fitrah manusia serta penjelasan mengenai manusia sebagai khalifah fil ardhi, yaitu bahwa ada ketentuan Allah yang pasti berlaku untuk setiap individu, apa yang diupayakan individu bisa terwujud hanya dengan izin Allah, musibah yang menimpa individu juga tidak mungkin terjadi tanpa izin Allah (Anwar, 2007). Bimbingan dan Konseling Islam adalah proses pemberian bantuan terarah, continue, dan sistematis kepada setiap individu agar ia dapat mengembangkan potensi atau fitrah beragama yang dimilikinya secara optimal dengan cara menginternalisasikan nilai-nilai yang terkandung di dalam Al-Qur'an dan Hadits tercapai dan fitrah beragama itu telah berkembang secara optimal maka individu tersebut dapat menciptakan hubungan yang baik dengan Allah, dengan manusia dan alam semesta sebagai manifestasi dari peranannya sebagai khalifah di muka bumi yang sekaligus juga berfungsi untuk mengabdi kepada Allah SWT. Pada akhirnya agar individu selamat dan memperoleh kebahagiaan yang sejati di dunia dan akhirat (Anwar, 2007).

Adapun Bimbingan Mendorong klien untuk menyadari dan menerima kehidupan yang diberikan Allah penuh keridhoan dan keihklasan (salah satu langkah pelaksanaan dalam Bimbingan Konseling Islam) agar fitrah yang dikaruniakan Allah kepada individu bisa berkembang dan berfungsi dengan baik. Selain itu juga mendorong klien memahami diri serta lingkungannya. Bimbingan dan Konseling Islam ini dipilih karena menurut peneliti sangat tepat dalam membantu para penyandang tunanetra dalam menyelesaikan permasalahan penerimaan diri mereka dan akan sangat efektif dalam meningkatkan penerimaan diri mereka, hal ini dikarenakan Bimbingan dan konseling Islam tidak hanya bertujuan agar individu atau para penyandang tunanetra sehat secara mental atau psikologis yaitu memiliki penerimaan diri yang baik, akan tetapi juga bertujuan untuk kebahagiaan dunia dan akhirat yang diinginkan oleh setiap individu sebagai makhluk beragama.

Adapun rumusan masalah dalam penelitian ini adalah sebagai berikut "Apakah Bimbingan Konseling Islam dapat Meningkatkan Penerimaan Diri pada Penyandang Tunanetra?". Tujuan dari Penelitian ini yaitu untuk mengetahui keefektifan penggunaan Bimbingan dan Konseling Islam dalam meningkatkan Penerimaan Diri Pada Penyandang Tunanetra. Hipotesis yang diajukan dalam penelitian ini yaitu Bimbingan Konseling Islam Efektif dalam Meningkatkan Penerimaan Diri Pada Penyandang Tunanetra

\section{Metode}

Adapun jenis penelitian ini yaitu peneltian eksperimen. Desain eksperimen yang digunakan dalam penelitian ini yaitu Quasi-Eksperimental pretest-posttest one group design. Subjek yang digunakan dalam penelitian ini berjumlah 5 (lima) orang mahasiswa-mahasiswi penyandang Tunanetra yang dinaungi oleh Pusat Layanan Difabel (PLD) Universitas Islam Negeri Sunan Kalijaga Yogyakarta.

Alat pengumpulan data menggunakan skala Penerimaan diri yang mengacu pada aspek penerimaan diri yang dikemukakan oleh Sheerer. Analisis data menggunakan wilcoxon signed rank test dengan program SPSS 16.00 for windows. Analisis data tersebut membedakan dua data dari dua kali pengujian, atau dalam penelitian ini data prestest-posttest dan posttest follow up, dari satu kelompok subjek penelitian, untuk mengetahui adanya perubahan sebelum dan sesudah diberikan perlakuan.

\section{Hasil dan Pembahasan}

Berdasarkan uji statistik hasil uji beda (uji hipotesis) Wilcoxon Signed Rank Test diperoleh Asymp.Sig. (2-tailed) atau $p=0,043$, dimana $p=0,01<p<0,05$. Hal ini menjelaskan bahwa ada perbedaan yang signifikan antara pretest dan posttest Penerimaan diri penyandang Tuna Netra. Berdasarkan hasil perhitungan statistik ini berarti Bimbingan dan Konseling Islam efektif untuk meningkatkan Penerimaan Diri pada penyandang Tuna Netra. Dengan demikian hipotesis yang diajukan peneliti dalam penelitian ini diterima atau terbukti.

Adapun uji statistik pada ketujuh aspek hasil uji beda menggunakan wilcoxon signed rank test diperoleh sebagai berikut:

Pertama, aspek keyakinan akan kemampuan dalam menghadapi problem kehidupan diperoleh Asymp.Sig. (2-tailed) atau $\mathrm{p}=0,496$, dimana $\mathrm{p}=0,01<\mathrm{p}<0,05 \mathrm{Hal}$ ini menjelaskan bahwa ada perbedaan yang signifikan antara pretest dan posttest aspek keyakinan akan kemampuan dalam menghadapi problem kehidupan. Dengan interval peningkatan antara pretes dan post-test yaitu sebesar 5 poin. 
Kedua, aspek harga diri sebagai manusia yang sederajat dengan orang lain diperoleh Asymp.Sig. (2tailed) atau $p=0,42, p=0,01<p<0,05 \mathrm{Hal}$ ini menjelaskan bahwa ada perbedaan yang signifikan antara pretest dan posttest aspek harga diri sebagai manusia yang sederajat dengan orang lain. Dengan interval peningkatan antara pretes dan post-test yaitu sebesar 20 poin.

Ketiga, aspek perasaan tidak menyimpang dan berbeda dengan orang lain (tidak minder) diperoleh Asymp.Sig. (2-tailed) atau $\mathrm{p}=0,41, \mathrm{p}=0,01<\mathrm{p}<0,05 \mathrm{Hal}$ ini menjelaskan bahwa ada perbedaan yang signifikan antara pretest dan posttest aspek perasaan tidak menyimpang dan berbeda dengan orang lain (tidak minder). Dengan interval peningkatan antara pretes dan post-test yaitu sebesar 15 poin.

Keempat, aspek sadar dan merasa tidak malu akan dirinya diperoleh Asymp.Sig. (2-tailed) atau $p=0,63, p>0,05$. Hal ini menjelaskan bahwa tidak ada perbedaan yang signifikan antara pretest dan posttest aspek sadar dan merasa tidak malu akan dirinya. Meskipun tidak adanya perbedaan yang signifikan, pada aspek ini terjadi peningkatan skor pretes dan posttest, hal ini terlihat dari interval peningkatannya yaitu sebesar 18 poin.

Kelima, aspek tanggung jawab terhadap perilakunya diperoleh Asymp.Sig. (2-tailed) atau $p=0,63$, $p>0,05$. Hal ini menjelaskan bahwa tidak ada perbedaan yang signifikan antara pretest dan posttest aspek tanggung jawab terhadap perilakunya. Meskipun tidak adanya perbedaan yang signifikan, pada aspek ini terjadi peningkatan skor pretes dan posttest, hal ini terlihat dari interval peningkatannya yaitu sebesar 19 poin.

Keenam, aspek objektif dalam menerima pujian atau celaan atas dirinya diperoleh Asymp.Sig. (2tailed) atau $p=0,43 p=0,01<p<0,05 \mathrm{Hal}$ ini menjelaskan bahwa ada perbedaan yang signifikan antara pretest dan posttest aspek objektif dalam menerima pujian atau celaan atas dirinya. Dengan interval peningkatan antara pretes dan post-test yaitu sebesar 15 poin.

Ketujuh, aspek tidak adanya penyalahan diri atas keterbatasan yang dimiliki ataupun pengingkaran kelebihan diperoleh Asymp.Sig. (2-tailed) atau $p=0,68, p>0,05$. Hal ini menjelaskan bahwa tidak ada perbedaan yang signifikan antara pretest dan posttest aspek tidak adanya penyalahan diri atas keterbatasan yang dimiliki ataupun pengingkaran kelebihan. Meskipun tidak adanya perbedaan yang signifikan, pada aspek ini terjadi peningkatan skor pretes dan posttest, hal ini terlihat dari interval peningkatannya yaitu sebesar 15 poin.

Berdasarkan penjelasan diatas, dari ketujuh aspek yang sangat signifikan peningkatannya melalui uji wilcoxon yaitu aspek perasaan tidak menyimpang dan berbeda dengan orang lain (tidak minder) dengan Asymp.Sig. (2-tailed) atau $\mathrm{p}=0,41, \mathrm{p}<0,05$ dan interval peningkatan sebesar 15 poin. Hal ini menjelaskan bahwa aspek perasaan tidak menyimpang dan berbeda dengan orang lain (tidak minder) perasaan tidak menyimpang yang sangat efektif peningkatannya setelah melalui proses Bimbingan dan Konseling Islam. Sedangkan aspek yang sangat tidak siginifikan peningkatannya melalui uji wilcoxon yaitu aspek tidak adanya penyalahan diri atas keterbatasan yang dimiliki ataupun pengingkaran kelebihan dengan Asymp.Sig. (2-tailed) atau $p=0,68$ dimana $p>0,05$. Hal ini menjelaskan bahwa aspek tidak adanya penyalahan diri atas keterbatasan yang dimiliki ataupun pengingkaran kelebihan sangat tidak efektif peningkatannya setelah melalui proses Bimbingan dan Konseling Islam.

Tabel 1. Interval peningkatan setiap aspek dari Penerimaan Diri (pretest-posttest)

\begin{tabular}{|c|c|c|c|c|}
\hline No & Aspek & $\begin{array}{l}\text { Jumlah total } \\
\text { skor Pretest }\end{array}$ & $\begin{array}{l}\text { Jumlah total } \\
\text { skor Post-test }\end{array}$ & $\begin{array}{c}\text { Interval } \\
\text { peningkatan }\end{array}$ \\
\hline 1 & $\begin{array}{l}\text { Keyakinan akan kemampuan dalam } \\
\text { menghadapi problem kehidupan }\end{array}$ & 102 & 107 & 5 \\
\hline 2 & $\begin{array}{l}\text { Harga diri sebagai manusia yang } \\
\text { sederajat dengan orang lain }\end{array}$ & 68 & 88 & 20 \\
\hline 3 & $\begin{array}{l}\text { Perasaan tidak menyimpang dan } \\
\text { berbeda dengan orang lain (tidak } \\
\text { minder) }\end{array}$ & 87 & 102 & 15 \\
\hline 4 & $\begin{array}{l}\text { Sadar dan merasa tidak malu akan } \\
\text { dirinya }\end{array}$ & 103 & 121 & 18 \\
\hline 5 & Tanggung jawab terhadap perilakunya & 38 & 57 & 19 \\
\hline 6 & $\begin{array}{l}\text { Objektif dalam menerima pujian atau } \\
\text { celaan atas dirinya }\end{array}$ & 125 & 140 & 15 \\
\hline 7 & $\begin{array}{l}\text { Tidak adanya penyalahan diri atas } \\
\text { keterbatasan yang dimiliki ataupun } \\
\text { pengingkaran kelebihan }\end{array}$ & 54 & 69 & 15 \\
\hline
\end{tabular}


Tabel 2. Kategorisasi masing-masing subjek post-test

\begin{tabular}{|c|c|c|c|c|}
\hline Kategorisasi & Rumus & Skor & $\begin{array}{c}\text { Jumlah } \\
\text { subjek }\end{array}$ & Prosentase \\
\hline Rendah & $\mathrm{X}<\mathrm{M}-1 . \mathrm{SD}$ & $\begin{array}{c}\mathrm{X}<100-1.40 \\
\mathrm{X}<60\end{array}$ & 0 & $0 \%$ \\
\hline Sedang & $\begin{array}{l}X<-1 . S D X<M \\
+1 . S D\end{array}$ & $\begin{array}{c}\mathrm{X}<60-1.40 \mathrm{X} 100+1.40 \\
\mathrm{X}<60 \mathrm{X}<140\end{array}$ & 3 & $60 \%$ \\
\hline Tinggi & $\mathrm{M}+1 . \mathrm{SD}<\mathrm{X}$ & $\begin{array}{c}100+40<140 \\
140>140\end{array}$ & 2 & $40 \%$ \\
\hline
\end{tabular}

Tabel 3. Kategorisasi dan interval peningkatan

\begin{tabular}{ccccccc} 
No & $\begin{array}{c}\text { Nama } \\
\text { Subjek }\end{array}$ & $\begin{array}{c}\text { Skor Total } \\
\text { pretest }\end{array}$ & Kategorisasi & $\begin{array}{c}\text { Skor Total } \\
\text { post-test }\end{array}$ & Kategorisasi & $\begin{array}{c}\text { Interval } \\
\text { Peningkatan }\end{array}$ \\
\hline $\mathbf{1}$ & WL & 122 & Sedang & 136 & Sedang & 14 \\
$\mathbf{2}$ & MI & 110 & Sedang & 140 & Tinggi & 30 \\
$\mathbf{3}$ & AS & 105 & Sedang & 128 & Sedang & 23 \\
$\mathbf{4}$ & PR & 118 & Sedang & 138 & Sedang & 20 \\
$\mathbf{5}$ & KRS & 132 & Sedang & 142 & Tinggi & 10 \\
\hline
\end{tabular}

Berdasarkan hasil analisi tabel 2 dan 3 diatas, hipotesis yang diajukan dalam penelitian ini diterima. Hal ini ditunjukkan dengan hasil uji beda menggunakan Wilcoxon Signed Ranks Test, dimana Asymp.Sig. (2-tailed) atau $p=0,043$, dimana $p=0,01<p<0,05$. Hal ini menjelaskan bahwa ada perbedaan yang signifikan antara pretest dan posttest Penerimaan diri penyandang Tuna Netra. Berdasarkan hasil perhitungan statistik ini berarti Bimbingan dan Konseling Islam efektif untuk meningkatkan Penerimaan Diri pada penyandang tunanetra. Dengan demikian hipotesis yang diajukan peneliti dalam penelitian ini diterima atau terbukti. Semakin efektif proses Bimbingan dan Konseling Islam, maka akan semakin meningkatkan Penerimaan Diri pada penyandang tunanetra, begitu juga sebaliknya semakin tidak efektif proses Bimbingan dan Konseling Islam yang diberikan, maka tidak akan efektif untuk meningkatkan Penerimaan Diri pada penyandang tunanetra.

Bimbingan Konseling Islami adalah proses pemberian bantuan terarah, continue, dan sistematis kepada setiap individu agar ia dapat mengembangkan potensi atau fitrah beragama yang dimilikinya secara optimal dengan cara menginternalisasikan nilai-nilai yang terkandung di dalam al-Qur'an dan hadis tercapai dan fitrah beragama itu telah berkembang secara optimal maka individu tersebut dapat menciptakan hubungan yang baik dengan Allah, dengan manusia dan alam semesta sebagai manifestasi dari peranannya sebagai khalifah di muka bumi yang sekaligus juga berfungsi untuk mengabdi kepada Allah SWT. Pada akhirnya agar individu selamat dan memperoleh kebahagiaan yang sejati di dunia dan akhirat. Mendorong klien untuk menyadari dan menerima kehidupan yang diberikan Allah penuh keridhoan dan keihklasan (salah satu langkah pelaksanaan dalam Bimbingan Konseling Islam) agar fitrah yang dikaruniakan Allah kepada individu bisa berkembang dan berfungsi dengan baik.

Ada beberapa unsur di dalam Bimbingan dan Konselining Islami yaitu mendorong klien untuk memahami diri, pemahamn terhadap lingkungan, kesadaran diri, pengendalian diri, dan menerima ketentuan yang ditetapkan padanya (hal ini berkaitan dengan aspek yang ada dalam penerimaan diri yaitu sadar dan merasa tidak malu akan dirinya). Mendorong klien mampu untuk mengambil keputusankeputusan strategis yang bersisi sikap dan perilaku yang baik bagi terselesaikannya masalah yang sedang dihadapinya (adapun dalam aspek penerimaan diri yaitu individu bertanggung jawab terhadap perilakunya, dimana individu memiliki keberanian untuk menghadapi dan menyelesaikan segala resiko yang timbull akibat dari perilakunya). Semakin individu didorong untuk mampu memahami diri, mengenali diri serta fitrah atau potensi dirinya, maka hal ini akan semakin mampu membantu individu dalam meningkatkan penerimaan dirinya.

Adapun dalam sebuah penelitian menunjukkan bahwa individu yang dilatih untuk mengenal dirinya dapat meningkatkan penerimaan dirinya. Dimana dengan mengetahui kelebihan maupun kekurangan dirinya salah satu cara untuk membantu individu memperoleh self-knowledge dan self-insight yang sangat berguna bagi proses penyesuaian diri yang baik dan merupakan salah satu kriteria mental yang sehat. Self-knowledge membutuhkan suatu kemampuan untuk menemukan aset pribadi yang 
dimiliki sehingga kelemahan-kelemahan yang ada dapat dikurangi atau dihilangkan. Pengetahuan tentang diri ini akan mengarah pada self-objectivity dan penerimaan diri (Handayani, Ratnawati, \& Helmi, 1998). Semakin efektif pemberian Bimbingan dan Konseling Islam, maka akan semakin efektif dalam meningkatkan penerimaan diri pada penyandang Tuna Netra.

Dari hasil penelitian yang menunjukkan adanya perbedaan yang signifikan antara pretest dan posttest Penerimaan diri penyandang Tuna Netra, pada variabel Penerimaan diri tersebut maka peneliti membuat kategorisasi subjek berdasarkan skor masing-masing subjek ke dalam tiga kategori yaitu rendah, sedang, dan tinggi. Adapun pada skala penerimaan diri ini diperoleh, $0 \%$ subjek masuk dalam kategori rendah, $60 \%$ subjek masuk pada kategori sedang yaitu berjumlah tiga subjek (subjek MI, AS, dan PR) dan $40 \%$ masuk pada kategori Tinggi yaitu berjumlah dua subjek (subjek WL dan KRS).

Berdasarkan kategori diatas, dapat disimpulkan bahwa penerimaan diri penyandang Tuna Netra skor tertinggi pada kategori sedang, hal ini mengindikasikan bahwa penerimaan diri penyandang tunannetra yang dinaungi oleh Pusat Layanan Difabel Universitas Islam Negeri Sunan Kalijaga Yogyakarta berada pada kategori sedang, akan tetapi yang berada pada kategori tinggi juga pada skor tertinggi kedua, yaitu $40 \%$ dari $100 \%$ subjek. Selain itu, meskipun berada pada kategori sedang, keseluruhan subjek mengalami peningkatan pada skor total penerimaan dirinya.

Hasil ini juga didukung oleh hasil wawancara pada sesi Bimbingan dan Konseling Islam subjek. Dimana pada awal sesi Bimbingan dan Konseling Islam para subjek mengungkapkan beberapa permasalahan yang terkait penerimaan diri mereka, diantaranya yaitu subjek mengatakan bahwa dari $100 \%$ penerimaan diri beberapa subjek berada pada $40 \%-60 \%$, dan ada juga yang berada pada $45 \%$. Selain itu juga mengatakan belum bisa menerima diri sepenuhnya sebagai penyandang Tuna Netra, kurang percaya diri, minder, pemalu, tidak mau membuka diri, masih ada perasaan kesal mengapa terlahir sebagai penyandang Tuna Netra, sulit menyesuaikan diri, dan menurunnya motivasi.

Adapun setelah dilakukan Bimbingan dan Konseling Islam, subjek-subjek mengungkapkan hal yang berbeda. Dimana mereka menunjukkan adanya kesadaran diri bahwa manusia memiliki kelebihan dan kekurangan, bersyukur dengan apa yang Allah SWT berikan dan tetapkan, merasa lebih baik dalam penerimaan diri mereka sekarang, menyadari bahwa apa yang terjadi dalam hiudp adalah ketentuan Allah SWT dan pasti ada hikmahnya, selain itu subjek banyak belajar dari kegiatan Bimbingan dan Konseling Islam ini, dan sekarang merasa mulai berpikir positif dan berusaha menerima semua ketentuan Allah SWT karena setiap manusia memiliki keunikan.

Adapun ada beberapa hal yang menyebabkan permasalahan maupun penrimaan diri subjek seperti yang mereka ungkapkan diantaranya pola asuh yang mereka terima dari orang tua mereka, ada yang dididik secara keras, ada yang diajarkan untuk selalu hidup mandiri sejak dari kecil, harapan yang tidak terealisasikan (terjadinya kegagalan yang berulang-ulang), tidak adanya dukungan dari lingkungan sosial (lingkungan yang kurang mengerti dan memahami kondisi mereka), kesulitan dalam bidang akademik, serta kurangnya kemampuan yang dimiliki.

Ada beberapa faktor yang dapat mempengaruhi penerimaan diri seseorang dan hal ini sesuai dengan hasil wawancara yang dilakukan pada subjek dalam penelitian ini, diantaranya yaitu baik faktor internal maupun faktor eksternal yaitu pemahman tentang diri, harapan yang realistis (dimana pada subjek yang selalu gagal dan mendapatkan sesuatu yang tidak sesuai dengan apa yang mereka harapkan memperburuk penerimaan diri mereka), penyesuaian diri dan sosial (kelima subjek mengungkapkan adanya kesulitan dalam penyesuain diri dan sosial mereka), kesuksesan dan pengetahuan diri (dimana dua subjek mengungkapkan bahwa mereka memiliki kesulitan dalam bidang akademik, dan bahkan ketika ditanyakan kemampuan yang dimiliki, satu subjek yaitu MI mengungkapkan tidak memiliki kemampuan apa-apa), padahal kemampuan ini sangat penting bagi individu untuk mencapai tujuan mereka.

Selain itu faktor lain yaitu faktor eksternal yang dapat mempengaruhi penerimaan diri subjek yaitu pola asuh yang baik dimasa kecil (satu subjek dididik dengan sangat keras yaitu subjek inisial AS, sehingga subjek sering merasa orang tuanya kurang menyayanginya, sedangkan kakaknya dididik tidak keras,satu subjek dengan inisial KRS dari kecil dididik untuk selalu hiudp mandiri dan hal ini terlihat penerimaan diri subjek yang tinggi dibanding subjek yang lain), dukungan sosial (beberapa subjek mengungkapkan bahwa masih banyak orang-orang disekitar subjek yang belum memahami dan mengerti kondisi subjek, padahal terkadang mereka sangat membutuhkan dukungan dari lingkungan sosial mereka, seperti teman kuliah, dosen, relawan dan pengurus Pusat Layanan Difabel (PLD).

Hal diatas juga didukung oleh beberapa penelitian, sebuah penelitian mengungkapkan bahwa pola asuh yang diterapkan oleh orang tua dapat mempengaruhi penerimaan diri (Ceyhan \& Ceyhan, 2011). Penelitian lain juga mengungkapkan bahwa lingkungan sosial juga mempengaruhi penerimaan diri (Decha-ananwong, Tuicomepee, \& Kotrajaras, 2013). Selain itu penelitian lain juga mengungkapkan bahwa dukungan sosial juga menjadi salah satu faktor yang mempengaruhi penerimaan diri (Ceyhan \& 
Ceyhan, 2011). Hal ini membuktikan bahwa faktor-faktor seperti pola asuh, lingkungan sosial serta dukungan sosial mempengaruhi penerimaan diri pada penyandang tunanetra.

Selain adanya perbedaan hasil dari pretest dan posttest, hasil penelitian terutama pada interval peningkatan, adanya perbedaan poin interval peningkatan antara subjek laki-laki dan perempuan, dimana pada subjek perempuan, poin interval peningkatannya lebih besar dibandingkan subjek laki-laki, hal ini didukung oleh sebuah penelitian, dimana hasil penelitian menunjukkan bahwa laki-laki dan perempuan memiliki penerimaan diri yang berbeda (Toyota, 2011). Selain itu penelitian lain juga menunjukkan hasil bahwa pada subjek perempuan penerimaan diri meningkat dalam rentang waktu empat tahun, sedangkan pada subjek laki-laki tidak ada perbedaan penerimaan diri dalam rentang empat tahun. Penelitian ini menggunakan studi longitudinal (Ceyhan \& Ceyhan, 2011). Dalam hal ini menunjukkan bahwa adanya peningkatan Penerimaan Diri pada penyandang tunanetra antara laki-laki dengan perempuan. Hasil penelitian diatas mendukung hasil penelitian dalam tesis ini, dimana dari hasil penelitian yang dilakukan oleh peneliti menunjukkan bahwa ada perbedaan penerimaan diri pada laki-laki dan perempuan.

\section{Kesimpulan}

Berdasarkan hasil penelitian yang telah dikemukakan, maka dapat diambil kesimpulan bahwa ada perbedaan yang signifikan antara pretest dan posttest Penerimaan diri penyandang Tunanetra pada mahasiswa yang dinaungi oleh Pusat Layanan Difabel Universitas Islam Negeri Sunan Kalijaga Yogyakarta. Yang ditunjukkan dengan hasil uji beda menggunakan Wilcoxon Signed Ranks Test, dimana Asymp.Sig. (2-tailed) atau $p=0,043$, dimana $p=0,01<p<0,05$. Berdasarkan hasil perhitungan statistik ini berarti Bimbingan dan Konseling Islam efektif untuk meningkatkan Penerimaan Diri pada penyandang Tunanetra. Hal ini mengindikasikan bahwa Semakin efektif proses Bimbingan dan Konseling Islam, maka akan semakin meningkatkan Penerimaan Diri pada Penyandang Tunanetra, begitu juga sebaliknya semakin tidak efektif proses Bimbingan dan Konseling Islam yang diberikan, maka tidak akan efektif untuk meningkatkan Penerimaan Diri pada penyandang tunanetra.

Adapun pada kategorisasi subjek berdasarkan skor yang diperoleh pada skala Penerimaan Diri penyandang tunanetra skor tertinggi pada kategori sedang $(60 \%)$, yaitu berjumlah tiga subjek yaitu subjek dengan inisial AS, PR dan MI. Sedangkan $40 \%$ berada pada kategori Tinggi. meskipun berada pada kategori sedang, keseluruhan subjek mengalami peningkatan pada skor total penerimaan dirinya.

Hasil diatas juga didukung oleh hasil wawancara pada sesi Bimbingan dan Konseling Islam subjek. Pada awal sesi Bimbingan dan Konseling Islam para subjek mengungkapkan beberapa permasalahan yang terkait penerimaan diri mereka, diantaranya yaitu subjek mengatakan bahwa dari $100 \%$ penerimaan diri beberapa subjek berada pada $40 \%$ - 60\%, dan ada juga yang berada pada $45 \%$. Selain itu juga mengatakan belum bisa menerima diri sepenuhnya sebagai penyandang tunanetra, kurang percaya diri, minder, pemalu, tidak mau membuka diri, masih ada perasaan kesal mengapa terlahir sebagai penyandang tunanetra, sulit menyesuaikan diri, dan menurunnya motivasi.

Adapun setelah dilakukan Bimbingan dan Konseling Islam, subjek-subjek mengungkapkan hal yang berbeda. Mereka menunjukkan adanya kesadaran diri bahwa manusia memiliki kelebihan dan kekurangan, bersyukur dengan apa yang Allah SWT berikan dan tetapkan, merasa lebih baik dalam penerimaan diri mereka sekarang, menyadari bahwa apa yang terjadi dalam hiudp adalah ketentuan Allah SWT dan pasti ada hikmahnya, selain itu subjek banyak belajar dari kegiatan Bimbingan dan Konseling Islam ini, dan sekarang merasa mulai berpikir positif dan berusaha menerima semua ketentuan Allah SWT karena setiap manusia memiliki keunikan.

Bimbingan Konseling Islam memiliki beberapa unsur yang dapat mempengaruhi penerimaan diri yaitu dimana dalam Bimbingan dan Konseling Islam mendorong klien untuk memahami diri, pemahamn terhadap lingkungan, kesadaran diri, pengendalian diri, dan menerima ketentuan yang ditetapkan padanya. Adapun hasil yang ditunjukkan diatas dapat juga dipengaruhi oleh hal lain selain unsur yang ada di dalam Bimbingan dan Konseling Islam tersebut, seperti yang diungkapkan oleh beberapa penelitian, faktor lain yang dapat mempengaruhi penerimaan diri seperti pola asuh, dukungan sosial, lingkungan, kesuksesan dan juga pengetahuan.

Berdasarkan penelitain yang dilakukan bahwa Bimbingan dan Konseling Islam efektif meningkatkan Penerimaan diri pada Penyandang Tuna Netra mahasiswa Difabel Pusat Layanan Difabel UIN Sunan Kalijaga Yogyakarta. 


\section{Referensi}

Anwar, S. (2007). Bimbingan dan Konseling Islami. Semarang: Widya Karya.

Azmil, S. N. (2013). Bimbingan Dan Konseling Islam Dengan Media Braille Dalam Meningkatkan Motivasi Diri Pada Penyandang Tuna Netra Di Desa Jedong Kecamatan Prambon Kabupaten Sidoarjo. UIN Sunan Ampel Surabaya.

Ceyhan, A. A., \& Ceyhan, E. (2011). Investigation of university students' self-acceptance and learned resourcefulness: A longitudinal study. Higher Education, 61(6), 649-661.

Decha-ananwong, P., Tuicomepee, A., \& Kotrajaras, S. (2013). Self-Acceptance of Sexual Orientation in Gay Men: A Consensual Qualitative Research. Asian Conference on Psychology \& the Behavioral Science Proceedings, 349-365.

Gultom, S. T. N., \& Budisetyani, I. G. A. P. W. (2018). Penerimaan diri difabel (different abilities people): studi tentang remaja tunanetra perolehan. Jurnal Psikologi Udayana, 5(2), 278-286.

Handayani, M. M., Ratnawati, S., \& Helmi, A. F. (1998). Efektifitas pelatihan pengenalan diri terhadap peningkatan penerimaan diri dan harga diri. Jurnal Psikologi, 25(2), 47-55.

Harimukthi, M. T., \& Dewi, K. S. (2017). Eksplorasi kesejahteraan psikologis individu dewasa awal penyandang tunanetra. Jurnal Psikologi Undip.

Hurlock, E. (n.d.). B (1976), Personality Development. Tata McGraw-Hill, New York.

Perianto, E. (2016). MINAT DAN MOTIVASI BELAJAR MAHASISWA BERKEBUTUHAN KHUSUS (Studi Deskriptif Pada Mahasiswa Tuna Netra). G-Couns: Jurnal Bimbingan Dan Konseling, $1(1)$.

Sari, E. P., \& Nuryoto, S. (2002). Penerimaan diri pada lanjut usia ditinjau dari kematangan emosi. Jurnal Psikologi, 29(2), 73-88.

Schultz, D. (1991). Psikologi pertumbuhan, model-model kepribadian sehat. Kanisius.

Somantri, S. (2006). Psikologi anak luar biasa. Bandung: Refika Aditama.

Toyota, H. (2011). Differences in relationship between emotional intelligence and self-acceptance as function of gender and ibasho (a person who eases the mind) of Japanese undergraduates. Psihologijske Teme, 20(3), 449-459.

Walęcka-Matyja, K. (2014). Adolescent personalities and their self-acceptance within complete families, incomplete families and reconstructed families. Polish Journal of Applied Psychology, 12(1), 59-74.

Yulianti, E. (2017). Pelaksanaan bimbingan Islam dalam menumbuhkan kepercayaan diri penyandang tunanetra di Yayasan Komunitas Sahabat Mata Mijen Semarang. UIN Walisongo.

Zulfa, A. (2009). PENERIMAAN DIRI PADA REMAJA PENYANDANG TUNA NETRA (di Bina Cacat Netra" BUDI MULYA", MALANG). University of Muhammadiyah Malang. 